\title{
Binaural Beat of Bringbrung Music
}

\author{
Made Bagus Permadi Putra \\ Universitas Pasundan \\ Bandung, Indonesia \\ made@unpas.ac.id
}

\begin{abstract}
Bringbrung is a ritual music in the tradition of society in the Kampung Cidadap Hilir, Ledeng, Kota Bandung. In each of Bringbrung performances, there is always a trance from the player and the audience. This phenomenon becomes the background of this research. One of the musical elements that are thought to be highly influential stimulates trance is binaural sensation. This article explains how the music of Bringbrung can produce binaural sensation so that it can stimulate trance on the players and the audience. The research methods used in this article use qualitative methods with a phenomenological approach. The data was collected through observation, interview notes taking, triangulation, and focus group discussion. The analyses of this research were taken through analysis of reduction data, data presentation, and conclusion. The results of the research that has been done show that binaural sensation has a significant contribution in stimulating trance during the show Bringbrung. Binaural sensation generated from the frequency difference of each Bringbrung instrument that has a range of o - $25 \mathrm{~Hz}$. The binaural sensation produced by Bringbrung music is certainly one of the proofs that ritual music in Indonesia has a therapeutic effect. Advanced research in the field is very important for the development of music therapy based on the musical traditions of Indonesia.
\end{abstract}

Keywords: music therapy, psychology of music, psychoacoustic

\section{Introduction}

The variety of traditional music in Indonesia is certainly very much, both profane and sacred, Sumardjo (2001). As the era progressed, the sacred tradition of art became harder to find, this could be caused by the lack of regeneration or the inability of the art to follow the progress of the more advanced times. One of the sacred traditions that we can find today is Bringbrung music from Kampung Cidadap Hilir, Ledeng, Kota Bandung. Bringbrung is a ritual in the allotment to ask for salvation, blessings, and gratitude to God. The Bringbrung name is taken from the sound of musical instruments "terebang" and "dogdog" sound like "bring" and "brung".

The "terebang" instrument in Bringbrung music is the same as the type of "terebang" or tambourine in West Java in general which is shaped like a basin/cup with a single skin membrane that is tightened using rattan and is 
estimated to have existed since 1135 AD, Beck (2013), while "dogdog" is a percussion instrument with a single skin membrane, conical in shape that is played by hitting it with a wooden stick or hand, Spiller (2004).

Bringbrung is played in an ensemble and accompanied by a dance at the end of the show. The show of Bringbrung either for religion ceremony or cultural ceremony has formed like a ritual or ceremony in general, the show of Bringbrung is still in the form of the indoor or outdoor show, in the show of Bringbrung ritual has classified into three parts which are opening that starts with a religious lecture by Dalang or mastermind, then proceed with chanting prayers to ancestor. The music show is playing on the second session after the opening and the music that will be played in this session is the main songs. The Bringbrung has a song which lyrics inspired by Barzanji book. The show of the main songs is definitely accompanied by "terebang" instrument and "dogdog". As for the songs that played which are Salam 1, Salam 2, and Salam 3. The last session is closing. In the closing, there is the closing ceremony in the form of chanting prayers and nyuguh kahurun. After the closing session, the show will proceed to bring Jamjami songs,

In this last session, Bringbrung music always shows the phenomenon of good trance of the players, dancers, and spectators.

The phenomenon of trance and possession in a musical engagement certainly cannot be separated from the music itself, although psychologically other factors such as; situations, places, suggestions, and ambiance can also be a trigger factor for trance and possession, Siswanto (2015).

Viewed from musicology, the music of Bringbrung has elements of music that can stimulate trance like; strophic, ostinato, repetition, tempo, and binaural. From some elements of the music, binaural is one of the elements of music that is very 
potential as a factor incentive trance and possessed.

Binaural is two tones with a small frequency difference, one in each ear, you will hear the beat clearly in the difference frequency between those two tones. Thus, if I ask you to use the headphone, and in your left ear I will play $300 \mathrm{~Hz}$ and in the right ear I will play $310 \mathrm{~Hz}$, you will hear the beat at $10 \mathrm{~Hz}$. This is a processing artefact in the brain, not the real sound. There are several anomalies on this beat: this beat is only formed if two tones are divided less than $26 \mathrm{~Hz}$, the maximum $30 \mathrm{~Hz}$, Thompson And Biddle (2013). The difference between two tones is used for changing the activity type of the brain, East (2016). Foster (1990) concluded that binaural beats can stimulate the brain so that it is in a relaxed and meditative state. The impact on the binaural beat is certainly different for each individual, but generally it takes 8 minutes to 30 minutes to feel the impact or sensation of the binaural beat, the difference in duration of each individual occurs due to differences in the individual's state of mind.

Music therapy certainly has many functions such as for children with special needs, for relaxation and so on, this research is aimed at exploring the potential of Indonesian traditional music elements, binaural beats as a relaxation stimulus and Theta waves in the brain (meditative states). binaural sensation or binaural beats becomes one of the most interesting focuses of the study because it has a significant impact on the process of music therapy with certain goals. This is the background in this article where most of the music tradition in Indonesia is ritual music that has similar characteristics to Bringbrung music.

\section{Research Method}

The study is qualitative with a phenomenological approach. According to Sugiyono (2012), qualitative research can be interpreted as a research method based on the philosophy of post- 
positivity. This research method is used to study the natural state of an object (rather than an experiment), which researchers use as a central tool.

Phenomenology is a qualitative research of Philosophy and psychology that is specifically focus in human's life experiences (Sociology). Bringbrung is hereditary traditional of art. The method of Phenomenology will perfectly useful in this aspect, because all the bringbrung's artists are very experienced on their knowledge of the music of bringbrung itself

The data collection process is performed in a triangulation process (combination) and the data analysis is performed recursively or qualitatively.

According to Sugiono (2012), the qualitative way to get depth data is some data that has substance. Qualitative methods can have a significant impact on your research. Qualitative methods mean directly telling the truth about the relationship between the researcher and the informant, the purpose of the research, and the subject.

The author conducted the research into the Bringbrung music with the trance phenomenon that occurred nowadays with the deep data and the purpose that have obtained during the research in the field, that aimed the data that have been collected can analyze the problem or trance phenomenon in the Bringbrung music. This matter is disclosed by Sugiono (2012) that in the qualitative method, the deep data should have substances.

\section{Binaural Sensation of Bringbrung Music}

Binaural beats are the phenomenon of hearing that was discovered in 1839 by Heinrich Wilhelm Dove. He found that binaural beating (an actual wah-wah effect similar to vibrato) took place when separate frequencies were introduced into each ear, Thompson, And Biddle (2013). 
Binaural also requires an interval between two tones having a difference of not more than $25 \mathrm{~Hz}$, when the distance/frequency interval of the tone is more than 25 $\mathrm{Hz}$, our brain cannot detect any binaural sensation between that frequency (Woodward, 2014). Binaural can give a different sound sensation in each ear, the sounds are then combined in the brain into a beat or tap. The tap that we hear is actually different between each ear and each individual. From the results of field research, researchers found a frequency range that can lead to the occurrence of binaural beats on the listeners of songs on Bringbrung music. Here is the frequency of each instrument.

\begin{tabular}{|l|l|}
\hline \multicolumn{1}{|c|}{ Instrument } & \multicolumn{1}{c|}{ Frequency } \\
\hline Terebang 1 $(51 \mathrm{~cm})$ & $\begin{array}{l}\text { Bring: } 263 \mathrm{~Hz} \\
\text { Brung: } 144 \mathrm{~Hz}\end{array}$ \\
\hline Terebang 2 $(44 \mathrm{~cm})$ & $\begin{array}{l}\text { Bring: } 273 \mathrm{~Hz} \\
\text { Brung: } 154 \mathrm{~Hz}\end{array}$ \\
\hline Terebang 3 $(48 \mathrm{~cm})$ & $\begin{array}{l}\text { Bring: } 273 \mathrm{~Hz} \\
\text { Brung: } 154 \mathrm{~Hz}\end{array}$ \\
\hline Terebang 4 $(51) \mathrm{cm}$ & $\begin{array}{l}\text { Bring: } 273 \mathrm{~Hz} \\
\text { Brung: } 154 \mathrm{~Hz}\end{array}$ \\
\hline Terebang 5 $(52 \mathrm{~cm})$ & $\begin{array}{l}\text { Bring: } 263 \mathrm{~Hz} \\
\text { Brung: } 144 \mathrm{~Hz}\end{array}$ \\
\hline Terebang 6 $(52 \mathrm{~cm})$ & $\begin{array}{l}\text { Bring: } 263 \mathrm{~Hz} \\
\text { Brung: } 144 \mathrm{~Hz}\end{array}$ \\
\hline Dogdog & $\begin{array}{l}\text { Tung: } 293 \mathrm{~Hz} \\
\text { Plak: } 263 \mathrm{~Hz}\end{array}$ \\
\hline
\end{tabular}

Table 1.

Frequency of the Bringbrung instrument (Made, 2016)

In Bringbrung the difference of sound occurs when the instrument dieback sounds the tone of "bring" and "brung" simultaneously. The frequency is obtained when the "bring" tone is $263-275 \mathrm{~Hz}(12 \mathrm{~Hz}$ intervals) and the "brung" tone is 144 - $154 \mathrm{~Hz}$ (11 Hz interval). While the instrument dogdog frequency is at 263 on the tone "plak" and $239 \mathrm{~Hz}$ on the "tung". This, of course, leads to the sensation of binaural beat on the subject who listens to both the drummer, the dancer, and the Bringbrung artist because of the interval of no more than $25 \mathrm{~Hz}$ (ranging from $11-12 \mathrm{~Hz}$ ).

The binaural beat generated from Bringbrung music ranges from 5 - 15 $\mathrm{Hz}$, the binaural frequency variant occurs due to the soft sound produced by the instrument, the loud noise produced by hitting the instrument, the harder the instrument hits the harder the sound and the greater amplitude of the resulting frequency, 
consequently the sound frequency will change slightly high $\mathrm{o}-10 \mathrm{~Hz}$. The binaural beat on Bringbrung music has an important role in the process of possession, from various studies, Foster (1990) in Tamasio dan Fabbro (2017), concluded that binaural beat can stimulate the brain so that it is in a state of relaxation and meditative. The impact for the binaural beat is different for each individual, but it generally takes 8 minutes to 30 minutes to feel the impact or sensation of the binaural beat, the difference in duration of each individual occurs because of differences in individual mind conditions.

Based on the above explanation we can see that the impact of the binaural beat can occur at least 30 minutes, we can imagine that the Bringbrung show lasts for 2-4 hours (tailored to the needs), no wonder if the impact of binaural beat caused by "bring and" brung " from Bringbrung music to stimulate the occurrence of trance in this art.

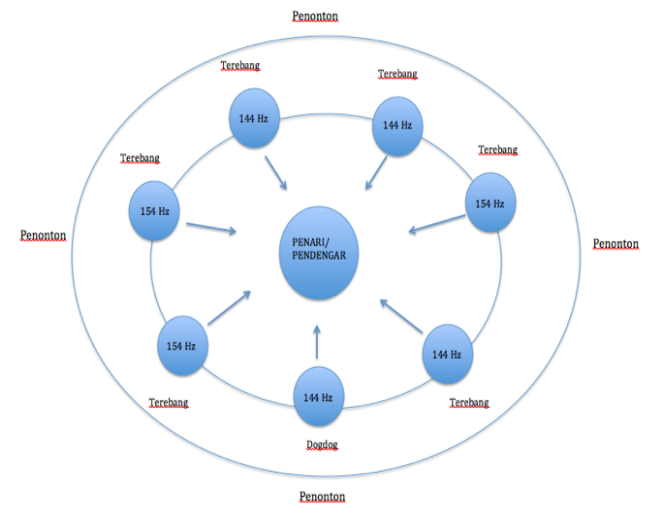

Fig. 1

simulation of the occurrence of a binaural beat on the tone "Brung"

The picture above is representing the image of the process of binaural beat generated by the sound of "Brung" to the dancer or audience in the arena. Meanwhile, the circle represents the sound correlation between each sound generated by the "terebang" and "dogdog" instrument, in other words, the musician also can hear the difference of the frequency that can give rise to the binaural beat. The outer ring represents the sound that has been generated and can be heard by the audience. Thus, the audience can sense the same feeling with the dancer and musician.

The binaural beat in Brinbrung music is thought to be one of the important factors in the stimulation 
process to achieve a state of relaxation, meditation and even an unconsciousness /trance. This became the culmination of the bringbrung music show. Trance in Bringbrung is certainly an important way of conveying social messages in human life. Generally, those who are in a trance can express either the emotions or feelings they experience in their lives. The showing expressions through a trance will certainly be a good "emotional regulation" because in a trance condition people will assume the subject is in an unconscious state, and will be more understanding because the subject is in a trance state.

\section{Conclusion}

Binaural that occurs in music Bringbrung is certainly very deliberate, this is certainly related to the tuning system instrument known in the tradition of music in Indonesia. Instrument tuning system with the term "nyurup" in the context of Bringbrung of course have the equation of the system with the tuning of traditional music from various regions in Indonesia, the system of tuning instrument or system of harmony is certainly different from the system of tuning and harmony of western music.

Binaural beat is founded on Bringbrung music and it has a system tunning called "nyurup". The functional of binaural beat on bringbrung can Stimulous the brain frequency to make a relaxation and even trance. This is the basis of the assumption that Indonesian traditional music in addition to the great history of sacred music for rituals, music traditions in Indonesia has characteristics as music that has therapeutic effects for its players and its audiences. Although not all music traditions in Indonesia have a therapeutic effect, most of the characteristics of Indonesian music have similarities with the music Bringbrung in this article. 


\section{References}

Barbara Tomasino \& Franco Fabbro.2017. Neuroimaging and Neuropsychology of Meditation States: Frontiers Media SA

Henry Spiller. 2004. Gamelan: The Traditional Sounds of Indonesia, Volume 1. California : ABC-

CLIO. Inc.

John H Beck. 2013. Encyclopedia of Percussion. New York : Routledge.

Made Bagus Permadi Putra. 2016. Tesis Fenomena Kesurupan Dalam Kesenian Bringbrung di Kampung Cidadap Hilir- Ledeng Kota Bandung

Marie Thompson \& Ian Biddle. 2013. Sound, Music, Affect: Theorizing Sonic Experience. Newyork: Bloomsbury Publishing.

Martin Wooward. 2014. Brainwave Entrainment Plus: Make Binaural Beats \& Isochronic Tones On Your PC for Hypnosis, Relaxation, Meditation \& More!: Lulu.Com

Siswanto. 2015. Psikologi Kesehatan Mental: Awas Kesurupan. Yogyakarta: Penerbit Andi.

Sugiyono. 2012. Memahami Penelitian Kualitatif. Bandung: Alfabeta.

First Author Made Bagus Permadi Putra gained Sarjana Seni degree in 2013 at Music Study Program, Universitas Pasundan and Magister Seni in 2016 at Art Study Program, Institut Seni Budaya Indonesia; a lecturer at Music Study Program, Faculty of Art and Letters, Universitas Pasundan; majoring Psychology of Music and Acoustic and Organology Instrument. current research interest in Psychoacoustic and developing musical instruments. 